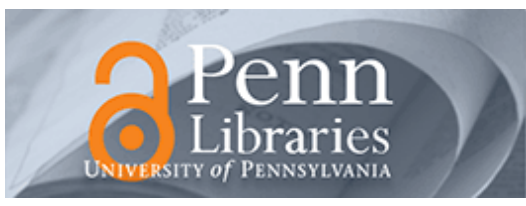

University of Pennsylvania
ScholarlyCommons

Departmental Papers (ASC)

Annenberg School for Communication

1993

\title{
Pioneers and Plain Folks: Cultural Constructions of "Place" in Radio News
}

Barbie Zelizer

University of Pennsylvania, bzelizer@asc.upenn.edu

Follow this and additional works at: https://repository.upenn.edu/asc_papers

Part of the Broadcast and Video Studies Commons

\section{Recommended Citation}

Zelizer, B. (1993). Pioneers and Plain Folks: Cultural Constructions of "Place" in Radio News. Semiotica, 93 (3-4), 269-285.

https://doi.org/10.1515/semi.1993.93.3-4.269

This paper is posted at ScholarlyCommons. https://repository.upenn.edu/asc_papers/673

For more information, please contact repository@pobox.upenn.edu. 


\section{Pioneers and Plain Folks: Cultural Constructions of "Place" in Radio News}

\section{Disciplines}

Broadcast and Video Studies | Communication | Social and Behavioral Sciences 


\section{Pioneers and plain folks: Cultural constructions of 'place' in radio news"}

BARBIE ZELIZER

Coriontemporary journalistic guidelines on how to present a news story sugguggest notions of 'place' as an index for news content, with the inverted pyroyramid and its emphasis on the 'where' of news a favored journalistic reciecipe for authenticating news discourse (i.e., Dary 1970; Garvey and Rivivers 1982). But in practice, and particularly in radio, references to 'place' areire employed by journalists in a partial and uneven fashion. In this article, I ci consider the 'where' of news presentation by examining how notions of 'plaplace' figure in radio news discourse. Discourse of two groups of radio jouournalists is examined: (1) that of American radio news, where 'place' is genenerally not an issue of border dispute; and (2) Israeli radio news, where 'plplace' is a central component of ongoing discourse about the country's righightful borders. 'Place' is thus seen not only as a physical location to whyhich news refers, but as a culturally-negotiated term by which journalists dralraw upon larger ideological discourses in relating the news.

I In the following pages, I consider general characteristics of radio newstalkalk and explore how representations of 'place' are employed within it. Rakadio journalists are shown to draw upon three separate cultural discourses in on constructing notions of 'place' - institutional talk, pioneering talk, and plalain talk. Each lends a different cultural importance to 'place', suggesting thahat journalists use it not only to reference physical location but as a cultulturally negotiated term that helps embed their dispatches within larger idedeological discourses.

\section{Radadio news: A setting for shared notions of 'place'}

Radadio news offers specific ways in which to construct notions of 'place'. Thehe medium depends on a purely auditory mode of transmission; it functionions 'blindly', bereft of either visual images or printed texts (Crisell 1986). Its ts broadcasts are generally formal and stylized, employing punctuated speppech, a serious and brief performative style, clear language, and an 
assumed background of shared experience among audiences (Moss and Higgins 1984; Crisell 1986). News announcers sit before anonymous audiences that give them little immediate feedback, and they tend to avoid reflexive frame-breaking (Goffman 1981; Bell 1982). Within these parameters, the radio broadcast is what Hymes (1972) calls a 'communicative event', a culturally-defined social event conceived as being appropriate for distinct forms of communication.

Journalistic constructions of 'place' are situated within such a framework. Journalists use place-terms to establish a story's location (i.e., Bittner and Bittner 1977). But place-terms are also used to delineate authority, pinpoint information (Hallin 1986), make social connections (Schegloff 1971), or serve as a news item's subject. When a radio announcer discusses 'a U.N. convoy carrying food and medical supplies into one Beirut-area camp' (KYW News), the U.N. reference has as much to do with 'place' as with representations of institutional presence and authority.

This paper thus examines how journalists use notions of 'place' to index larger concerns about the workings of culture and ideology. How is 'place' used in radio news? What does it reference? What does it hide? How does its usage differ across cultures? In order to address these questions, journalistic references to 'place' on American and Israeli newscasts were examined for one week during the spring of 1987 , both on a local 'all news' NBCaffiliate station in Philadelphia (KYW Newsradio) and on hourly newscasts on Israel's national state-run radio, Kol Yisrael (The Voice of Israel). Translations were provided by the author.

\section{Metonymic representations of 'place'}

Journalists have traditionally constructed notions of 'place' through two aspects of news performance - the place of event and the place of reporter covering the event. Journalistic stylebooks have long stipulated that both should be made clear. ${ }^{1}$ They hold that the place of event is most directly linked to 'lead sentences', phrases by which news stories are introduced and keyed to audiences (Hallin 1986; Schudson 1978; Brooker-Gross 1985). Journalists are advised to orient audiences directly to an event through its 'who, what, where, when and how'. Guidebooks similarly connect the place of reporter to 'datelines', conventions by which reporters use the locale in which they are situated to sign on or off, depending on the medium (Schudson 1986; Hallin 1986).

Yet in practice, radio journalists, like journalists in other media, routinely use notions of 'place' to indicate things other than the location of either 
event or reporter. ${ }^{2}$ Journalists regularly invoke 'place' to signify the following:

- Settings for institutions. In constructing notions of 'place', locations often stand in for the institutions situated there. Mention of Washington in a KYW News item references governmental activities. Kol Yisrael's reference to Tel Aviv in a story on the military immediately connotes the military headquarters located there.

- Delineations of ideological segmentations of space (such as the 'free world' versus 'the Communist world'). In both American and Israeli radio news, ideological segments of space are presented as givens of news discourse:

North Korea and Japan are in a standoff in a case involving eleven North Koreans who defected last month and two Japanese seamen accused of spying .... (KYW News)

Israel has asked the Soviet Union for permission to fly emigrating Jews directly to Israel .... (Kol Yisrael)

Jordanian Prime Minister Hussein said he does not intend to visit Washington next month, because, in his eyes, Washington has not paid sufficient attention to the problems of the Palestinian people. (Kol Yisrael)

The lexical juxtapositions through which these stories are structured (North Korea versus Japan, Israel versus the Soviet Union, Jordan versus Washington) reflect distinctions which separate the 'free world' from the rest of the globe. References to 'place' are thus employed as representations of ideological blocs.

- Practices or personalities associated with certain locations. KYW News refers to 'stock-trading' for Wall Street, 'diplomatic talks' for Washington, 'political think tank' for Washington, 'Vice-President George Bush' for Washington, and 'the White House' for the American government. Kol Yisrael uses 'diplomatic talks' for Jerusalem, 'Bank Israel' for Jerusalem, 'peace-keeping forces' for Sinai or Lebanon, 'diamond trading' for the Israel Diamond Exchange in Ramat Gan, and 'the Knesset' for Israeli Congressional practices. ${ }^{3}$

These examples, while anecdotal, suggest that journalistic formulations of 'place' in radio news go beyond those stipulated by professional guidelines. They are generally not confined to lead sentences and datelines that convey place of reporter or place of event. Rather, radio journalists use 'place' to attend to other cultural and ideological discourses at play in the news, using place-terms to embed their news relays within them.

This is accomplished by employing journalistic constructions of 'place' 
as metonymic representations. Journalists generate conceptualizations of one thing by means of its relation to something else. These representations display a partial but suggestive range of objectives accomplished by journalists in place-naming. In addition to location formation, journalists use terms of 'place' to signify buildings, people, and practices; to name institutions and governments; to distinguish between ideological blocs; and to provide settings for institutions. At the same time, place-terms are not mentioned in cases where other terms are used for place-formation. Mentioning Bank Israel is seen as a sufficient way to reference Jerusalem. This suggests that journalists alert audiences to a news item's location not only through 'place' but through 'place'-related discursive practices - naming familiar people (correspondents or politicians); naming familiar practices (stock market or diamond trading); or naming familiar institutions and institutional affiliations (governments or banks). Journalists thus familiarize audiences with uses of place-terms that have little to do with placeformation but much to do with institutional life. Similarly, journalists name practices, personalities, and institutions through their settings, reinforcing potentially problematic links between the 'natural' character of place-terms and the ideological motivations or constructedness of activities taking place therein. Referencing the 'free world' thus reinforces what appears to be a natural segmentation of space, with little explication of the institutional processes that constitute it.

\section{Institutional talk: An umbrella category for radio news}

The metonymic character of journalistic notions of 'place' necessitates considerations of 'the whole' referenced by such representations. Constructions of 'place' appear to be directly motivated by the presence of institutions. Journalists reference institutional settings, personalities, practices, and affiliations in their radio news-talk. Institutions are employed as viable substitutes for place-terms - the White House, the U.N., the Knesset. Similarly, place-terms, like Washington or Jerusalem, often reference the institutions situated there. These metonymic representations allow journalists to reference the whole of institutional life through the place-term they use to invoke aspects thereof. In both American and Israeli radio news, journalists thereby construct the 'where' of news via an institutional bias in radio news. I call this kind of discourse institutional talk.

How institutional talk spreads across levels of spatial particularization can be visualized in the continuum shown in Figure 1. It translates the levels of symbolic representation through which 'place' can be signified into spatial terms. These levels reflect a 'nesting' of spatial frames, through 


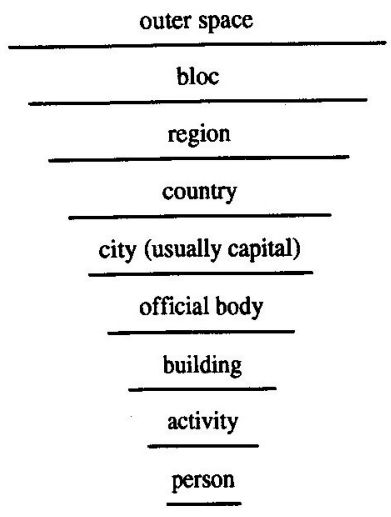

Figure 1 Levels of spatial particularization.

which references to 'place' move 'in toward' or 'out from' infinity. In institutional talk, each place-term fits into one of these levels, and in true metonymic form is referentially adequate to communicate about 'place'.

Institutional talk offers journalists a way to particularize 'place' through region, official body, or person. The most concrete (and only literal) placeterms - the locational indicators - are situated somewhere in the continuum's center (city or country). This suggests that the general is seen through the most particularistic, with the 'event' (if there is one) generally greater than the sense of 'place' through which it is made understandable. Placeformulation in radio news thus constitutes an 'outward-in' discourse, with the more general culture made intelligible through the particulars of one locale. In such a light, KYW News concretizes the larger war in Lebanon through the 'camps-war', while discussions of the East German President's visit to West Germany are confined to the city of Bonn. Similarly, Kol Yisrael discusses Israeli Prime Minister Yitzhak Shamir's trip to the U.S. through his movement in and out of his hotel. Institutional talk thereby tightens notions of 'place', with public events, values, and norms translated into private experience.

It is important to note that institutional talk is particularly attractive to journalists because, in focusing on the doings of elites and institutions in capital cities, it aligns them with elite-based practices of sourcing and news gathering (Tuchman 1978). Institutional talk also recalls classic journalistic norms of objectivity, neutrality, and accuracy, so labeled by the sociological literature (Tuchman 1978; Gans 1979). As Condit and Selzer (1985) have suggested, the rhetoric of news is structured via its compatibility with these norms. Institutional talk thereby addresses the 'where' of journalistic catechism. By employing it, journalists are (a) aligned with an institutional 
perspective on the world, and (b) reified as professionals. Talking about 'place' via institutions (and using institutions to substitute for more direct references to 'place') thus has much to do with a journalist's professional identity, institutional affiliation, and institutional overview of events. This, then, is the larger background of radio news-talk. Institutional talk provides the umbrella category for constructing 'place' in all kinds of radio news.

But does it exist across cultures? It is here that the distinction between American and Israeli radio news becomes most relevant, for the two cultures suggest an a priori different approach to notions of 'place': in Israel, 'place' is a term of considerable cultural contestation, regularly employed in discourse about the country's rightful borders; in the U.S., 'place' is a considerably more neutral term, not subject to the same degree of discourse about borders and boundaries. It thus makes sense to expect different embedded discourses within institutional talk that splinter usage of place-terms along Israeli and American cultural lines.

\section{Israeli news-talk: The pioneering ethos}

Embedded discourses of institutional talk feature many of the strategies seen in the umbrella category: ${ }^{4}$ notions of 'place' are used as location formulators alongside other non-place terms, while place-terms are used for aims other than place-formulation. What differs here are the kinds of places referenced within the embedded discourse.

'Place' in Israeli radio news is in many cases taken at its most concrete level. 'Place' becomes 'land' or 'country'. Journalists discuss activities $b a$ 'aretz (in the land/country) rather than b'medinah (in the state):

And in the country. Bank Leumi has lost its edge in recent days and Bank Hapoalim has become number one in the land. Our correspondent Gadi Sukenik reports that this is reflected in the 1986 fiscal statements of both banks, due to be published shortly.

Radio announcers use oo'ba'aretz (and in the country) as a transitional structure to move within the broadcast from one item to another. This suggests that 'the land' or 'the country' are referentially adequate to formulate 'place' in Israeli radio news, without needing more specific placeterms such as city names.

One telling construction of 'place' by Israeli journalists is found in the different names given one location. 'Israel', for example, has many names: Medinat yisrael (the State of Israel) is the name given the area after it received statehood in 1948. But for many right-wing ideological groups, who derive legitimacy for their presence not from the state but from the 
Bible, the name eretz yisrael (the Land of Israel) connotes an area of wider geographical boundaries. Derived from Biblical sources (Genesis, ch. 12) and revived by the right-wing Likud party during the late 1970s, its incorporation in discourse connotes an area which includes the controversial occupied territories. Attempts by extreme right-wing groups in the late 1980 s to set up a state called yehuda (Judea) in the occupied territories were similarly motivated by Biblical sources.

Thus on radio, yisrael (Israel) is invoked in an item about development in the north, while eretz yisrael (the Land of Israel) is cited in a story about settlement activity in Gush Etzion. Similarly, ha'aretz ha'kadosha (the Holy Land) is the name preferred by Christian evangelicals, while falastin is favored by Palestinians. Deputy Prime Minister David Levy discusses settlements on either side of hakav hayarok (the green line) - the expression for the ideological segmentation of space on Israel's eastern border with Jordan - while the West Bank of the Jordan River is alternately called yehudah v'shomron (Judea and Samaria) in an item discussing right-wing settlements; ha'shtachim (the territories) or ha'shtachim hamuchzakim (the administered territories) in items on Arab dignitaries or the closing of West Bank universities; or ha'gadah ha'maaravit (the West Bank). Less neutral labels might have included ha'shtachim ha'kvushim (the occupied territories). The same patch of land, then, can be treated differently according to topic. This suggests that topic helps Israeli radio journalists decide which cultural notion of 'place' to invoke.

Different invocations of 'place' reflect the salience of different cultural and ideological issues. These issues often correspond to a temporal order: for example, the term eretz yisrael (the Land of Israel) - after regaining social currency from the political right during the late 1970 s - has been adopted by more extremist groups advocating a Greater Land of Israel. Ha'aretz ha'kadosha (the Holy Land) is a Biblical notation employed generally by Christians both before and after the State's establishment, but is not usually heard on radio news. Falastin (Palestine) is the Arabic name for the region before it received statehood; this term has been largely appropriated by Palestinians but is not generally used by Israelis or in Israeli news-talk.

Similar ideological differences are reflected in names given the West Bank of the Jordan River: Yehuda v'shomron (Judea and Samaria) is a historical name signifying debate over the area's ownership rights. When the Likud party came to power in the 1970 s, the territories were 'renamed' in accordance with what were considered their 'historical' origins, thereby generating a process of repair in broadcasting language. Directives stipulated changing the name of 'the occupied territories' to 'Judea and Samaria'. On the whole, this practice generally persists today, although 'occupied territo- 
ries' and 'territories' slip in when the item deals with the Palestinians. That a temporal dimension is invoked by different place-names - with each frozen at a different point in time - conveniently allows the rhetoric of different cultural ideologies to sidestep disputes caused by a temporal ranking of place-names. Larger themes of 'place', then, link news-items with ongoing cultural and ideological debates. News stories are as much linked with concrete locations as they are co-opted within ongoing ideological discourses about notions of 'place'.

This is exemplified by attempts to invoke 'place' through the notion of hit'yashvut (settlement). Hit'yashvut is a term borrowed from modern Zionism, connoting settlement on the Israeli side of the green line. Settlement on what used to be the Jordanian side of the green line is invoked by hit'nachlut (settlement). Thus toshavim (residents) provides the most neutral term for settlement activity, mit'yashvim (settlers) connotes settlement on the Israeli side of the green line, and mit'nachlim (settlers) connotes settlement on the other side of the green line. Who settles where is thus an issue of continuing debate reflected in news discourse:

Education Minister Yitzhak Navon has cautioned about development of an educational system only for the rich. On a visit to Tel Aviv, he said that already today there are settlements in the land where parents with means finance private lessons and extracurricular activities for their children, while parents who earn low incomes cannot afford to do so. (Kol Yisrael)

While sounding possibly antiquated to foreign ears, the term 'settlements in the land' is sufficiently particularistic for most Israelis to grasp inherent ideological connotations. Other references include yishuvim (settlements); a decision to generate an azor pituach bet ('B' development region) outside of Haifa; and mityash'vim vatikim (veteran settlers) in Ashkelon:

The inspector for education in the south fears that there will soon be schools only for Ethiopian students, if veteran settlers continue refusing to enroll their children in mixed schools. Inspector Nissim Elkayam said at the Knesset Committee on Education and Immigration that at the Yeshurun School in Ashkelon, in which 40 percent of the students are Ethiopian immigrants, only 5 pupils from veteran families have been enrolled for next year's first grade. This exacerbates a situation in which veteran settlers have already begun leaving neighborhoods where groups of Ethiopian immigrants are housed. (Kol Yisrael)

The location of 'veteran settlers' is never made evident, yet it informs the story's more general sense of 'place'. Similarly, Yeshurun School in Ashkelon never quite becomes the 'overall' location of the event, yet listeners understand that it represents a larger locale. Generalized notions of settlement similarly emerge via talk about ayarot pituach (development towns): 
Ddeputy Prime Minister David Levy discusses the granting of financial asssistance to yishuvim b'yehuda v'shomron (settlements in Judea and Saamaria) and to ayarot ha'pituach (the development towns).

It is important to note that embedded within Israeli talk of 'place' is the ncotion of process: the word 'settlers' (and not 'residents' or 'citizens'), like the word 'settlement' (and not 'residence'), indicates a sense of 'place' that is both goal-directed and processual. 'Place' is never left static, recalling the 'going' category of Linde and Labov (1975) that is constituted through 'spatialized action'. Interestingly, when news items related to 'settlement' or 'settlers' are translated into English by the English-language news service of Kol Yisrael (for foreign journalists and new immigrants), they often lose their 'pioneering' tone: 'settlers' become 'citizens' or 'residents', 'settlement' becomes 'residence'.

All of this suggests that the place-names adopted by Israeli journalists directly reflect ongoing ideological discourses. Differential relations to one patch of land, as exemplified in all of the above-mentioned cases, signify ideological patterning in journalists' choice of place-names. How this discourse relates to the umbrella category of institutional talk is best demonstrated through references to 'the state':

And in the country. Deputy Prime Minister David Levy is bitterly protesting tonight the Alignment's earlier failure to give assistance to settlements in Judea and Samaria and the development towns. ... David Levy concluded by saying that all settlements should be granted assistance. ... Says David Levy: 'Everyone is saying how good the government has been for the state.' (Kol Yisrael)

In a piece in which he has just discussed settlement policies in the country, Levy's concluding reference to the 'state' signals a switch in the level of discourse. Levy's talk of 'government' and 'state' may be one way of contextualizing 'talk of land/country' within the rubric of institutions, of which he is a part. This example demonstrates how an embedded discourse can give way to its umbrella category of institutional talk.

An item about accused Nazi war criminal John Demjanjuk illustrates a similar phenomenon:

In Jerusalem. This morning begins the trial of John Ivan Demjanjuk. The State of Israel is accusing him of war crimes, crimes against the Jewish people, crimes against humanity, and crimes against oppressed peoples. ... On the list of witnesses for the prosecution are 59 persons who will come from a number of places in the world. Among them are Poles who lived near the death camp .... (Kol Yisrael)

The item appears to switch from institutional talk to an embedded discourse of certain ideological dimension. By opening with a legalized reference to 


\section{B. Zelizer}

'the State of Israel', the issues are presented as relevant to 'institutionalized' concerns belonging to the state apparatus. While such an invocation is characteristic of forensic discourse, the story is then generalized as a phenomenon of interest to humanitarians everywhere, with witnesses from around the world, international crimes against humanity, and the presence of Polish citizens (a point of special interest to Israelis due to lack of diplomatic ties between the two countries). The story is thus taken beyond the borders of the state and opened up to the world at large. It may be here that the embedded discourse accords the story the appropriate perspective for Israelis, while institutional talk frames it with language that the outside world can understand.

The embedded discourse of Israeli radio news-talk, with its emphasis on land and country, settlement, process, and development, is here called pioneering talk. Discourse on the pioneering ethos directly links up with the world-view through which the State of Israel was established: Zionist ideology held that an independent Jewish homeland was to be erected atop ancient (Biblical) Jewish territory. Unlike the larger umbrella category of institutional talk, however, pioneering talk constitutes a generalized discourse about a particular action. It reflects an 'inward-out' approach, by which private experience (or the experience of the settlement or collective) is generalized onto the realm of the general. Private, then, becomes here public: the Demjanjuk story could have been seen as a local story, a drama inside a Jerusalem courtroom, but is instead made representative of a more general event. Witnesses coming from mispar me'komot ba'olam (a number of places in the world) uphold the story's international frame. This 'inwardout' approach is also found in many stories about settlements in 'outback regions': for example, a failed attempt to integrate Ethiopian immigrants at an Ashkelon school becomes the responsibility of all 'veteran settlers' everywhere in Israel. Moreover, stories are rarely constituted only through 'outback' regions: events in 'outback' regions are usually generalized through statements issued from merkaz ha'aretz (the center of the land/ country), in reference to Jerusalem or Tel Aviv. Settlers in Ashkelon are discussed by the Knesset Education Committee in Jerusalem; settlements in the country where wealthy children received private lessons are discussed by the education minister in Tel Aviv. Widening a sense of 'place' thereby constitutes an attempt to take the activity or event beyond itself; 'in the land/country' assumes a dual quality which makes it synonymous with 'Israel' at the same time that it references 'outback' areas that legitimate the pioneering ethos. ${ }^{6}$

Many points about 'place' in Israeli radio news depend upon the notion of process through which they are communicated. The processual aspect of 'place' offers journalists one way of incorporating the Biblical centrality 
of place with its more fragmented contemporary contexts. While a sense of process helps Israelis adjust to an emerging change in priorities over the nature of settlement and colonization (Newman 1984), in news too, a processual interpretation of 'place' acts as a transitional structure: it posits Israel neither here nor there, always sending it on its way to something else. Says anthropologist Don Handelman:

Israelis sense, even if they do not enunciate, that the shape of Israel is still being moulded, and that they are taking an active part (and have an active voice) in this shaping of the character of the state. (1984: 78)

Place, when seen through process, thereby connotes movement and change. Both parameters are basic to Zionist ideology and contemporary notions about the nature of Israel. This suggests that in subscribing to such notions of 'place', Israeli radio journalists also subscribe to an embedded ideological discourse about pioneering. Such a discourse exists in embedded form within institutional talk, suggesting a certain tacit contract between institutional concerns and the pioneering ethos in Israel.

\section{American news-talk: Pluralistic rights of plain folks}

As with pioneering talk, the embedded discourse of American radio news displays many strategies seen in institutional talk. Again, non-place terms are used for place-formation, and place-terms are used for aims other than place-formation. KYW News generally features the settings of everyday life - homes, streets, outdoor scenes, and public settings of all kinds:

The turnout was disappointing, but organizers of Farm Save Day in North Carolina say the results were positive. It focused attention on the plight of the financially strapped American farmer. Event organizers expected more than 20,000 farmers from around the country to show up in Elizabeth City for speeches and a barbecue, but only about a thousand attended. Former major league pitcher, now farmer, Catfish Hunter says .... One crop doctor says he can see thousands more farms across the nation going under unless there's help sent to them soon. (KYW News)

These settings offer an image of America that belongs to the "common people'. Features like the farm, the barbecue, even the major league baseball pitcher reinforce images of wholesomeness. In that sense, the failure of the American farm can even be appropriated as one example of the country's failure.

Everyday settings are used to give national or statewide stories a local bent, positioning them outside large institutions. A story about the distribution of condoms during spring break by hotel operators in Fort Lauderdale, 
Florida localizes a nationwide problem. AIDS is 'domesticated' when journalists mention local hotels, rather than institutionalized by journalists covering the Attorney General's press conference. U.S.-Iran relations are similarly domesticated by the homecoming of a native son:

A Kansas town welcomed home a native son yesterday, who was held by Iran. Hundreds of people gathered in Hays to greet Wall Street Journal reporter Gerald Seib. The journalist thanked the townsfolk for their prayers and support during the days he was detained by Iranian officials. ... (KYW News)

American radio news stories are also often structured through notions of 'place' which make everyone more rather than less equal. A story about a prep-school boy who killed himself on school grounds is told in the form of a saga that makes it applicable to everyone's teenage son. The rape of a prostitute with AIDS in Atlantic City becomes a near-empathetic search for the rapist.

Public street-settings are another element that binds much of the noninstitutional talk in American radio news. Philadelphia Mayor Wilson Goode chases an errant city sanitation worker through city streets. Elsewhere a gunman escapes through back roads with his cache:

A single gunman made off with an estimated half a million dollars last night by raiding an armored car in Amarillo. Texas. Police say the thief entered the car, handcuffed the guards, and drove the vehicle to a parking place. After fleeing to a waiting van, he disappeared. (KYW News)

Notions of 'place' begin in their most concrete form, with stories initiated through 'everyday' physical settings. Yet they do not remain on that level: unlike institutional talk, where symbolic settings (institutions or governments) are made intelligible via physical settings (towns or cities), the particularization of 'place' here is less important to the story than the symbolic ideals it embodies. While it could be argued that this mythic geography is characteristic of the presentations of most national media, specific place-indicators are used here less as devices for particularizing 'place' and more as symbolic representations of greater ideals.

Often 'place' is not particularized at all, but left under the rubric of some general abstract ideal:

Two pilots who wanted to fly around the globe in their single engine plane "Arctic Turn" say they'll have to wait until next spring to do it .... (KYW News)

Listeners learn that one pilot is from Philadelphia only midway through the story. This is because that 'particular' location is irrelevant to the story's theme of transcending boundaries. An item on street people simi- 
larly generalizes a special tribunal in Philadelphia into a larger national problem for the homeless, while a story about a symbolic public meltdown of war toys mentions only at the end that the demonstration took place in Los Angeles. The meltdown is contextualized more as a growing grassroots movement than a small gathering of anti-nuke freaks.

These examples suggest that it often makes little difference where any of these stories take place, because they are symbolic representations of something extending beyond themselves. When listeners hear that 'hotel operators in Fort Lauderdale, Florida are being asked to distribute condoms and information on AIDS', they hear less a story about Fort Lauderdale and more a placeless story about how AIDS is changing sexual mores. The city of 'Amarillo, Texas' has little bearing on the fact that a gunman makes off with $\$ 500,000$. Within the confines imposed by the connotative baggage that makes up popular culture, in effect it could have been the same story in many different settings.

Like pioneering talk, the embedded discourse of American radio news is also structured in an 'inward-out' fashion: journalists use the particular as a means of reaching the general. The particular plight of one journalist held captive in Iran is transformed into the collective celebration of the return of a native son to his home town. 'Place' is thus used to make private experiences into public, collective ones.

Non-institutional talk in American radio news, then, emerges from largely non-functional but familiar notions of 'place'. Settings are invoked which reflect the access of plain folks - the street, park, or beachfront and access is generalized to all. Talk is not of Washington, government institutions, stock markets, or diplomatic circles, but of non-elites, the plain folk. The particularistic focus of this discourse is on the workings of everyday life, practices, people and settings.

The embedded discourse of American radio talk can be called plain talk. While plain talk recalls a belief in 'America' that rests within much of institutional talk, the catalyzing force here is plain folks, not the government or President. Plain talk recalls the role of the press in the consolidation of American democracy during the 1800s (Schudson 1978; Alexander 1980). The ideological tenor of the early penny press - when newspapers began to reflect less the affairs of elites and more the affairs of a varied, urban and middle-class society, and the penny press was first to pursue the 'plain old news of everyday life' (Alexander 1980: 30) — promoted a public discourse concerned with moral reform, self-improvement, and nationbuilding. Plain talk is thus rooted in a public discourse which accords rights to everyone, catering to romantic values of small-town pastoralism, tradition, individualism, and enterprise (Gans 1979). It links everyday places and people with earlier notions of pluralism and the rights of 
everyone. That plain talk in contemporary radio news focuses on the doings of common people - on demonstrations, field events, family activities, cultural caucuses, sports - therefore draws journalists in search of good stories. Plain talk gives journalists a clearer sense of how to talk about news which is not institutionally motivated. It also offers them a way to talk about non-institutional notions of 'place' in the news.

\section{Pioneers and plain folks: Cultural constructions of 'place'}

In this paper, I have suggested that newspeople invoke more than one notion of 'place' in radio news-talk. Moreover, they talk about the same notion of 'place' in more than one way. This paper suggests that 'place' has less to do with where the reporter is or where the event is, and more to do with where the perspective is. Perspective, in this case, constitutes whatever world-views (both institutional and ideological) are considered relevant by newspeople for discursively interpreting current events. Perspective offers journalists a way to combine both the place of event and the place of reporter within one larger semantic envelope. Two ways in which this works were proposed here:

(1) Institutional talk. This kind of news-talk, found in both American and Israeli radio news, links up with journalistic normative practices and values. It encourages journalists to appropriate news stories via an institutional perspective. Journalists come to view as natural the appropriation of a sense of 'place' through institutional personalities, practices, affiliations, or institutions themselves. Institutional talk thus gains legitimacy when journalists focus on the general through the particular. Via institutional talk, journalists concretize public events through private experience.

(2) Pioneering talk and plain talk. These embedded discourses take up where the umbrella category of institutional talk leaves off. They constitute interfaces between publics and the more formalized professional (and strictly institutional) values espoused by institutional talk. Pioneering talk and plain talk therefore offer a direct link with ongoing ideological discourses in society - in Israel with pioneering, in America with the glory of plain folks. The legitimacy of these embedded discourses is derived when journalists stress personal experience in order to generate larger ideological connections.

The co-opted presence of embedded discourses within an umbrella category of institutional talk suggests that both the pioneering ethos and the ascent of plain folks are seen within an institutional frame of reference. Institutional concerns provide the larger background against which discourse about pioneering and plain folks is made meaningful. 
At the same time, the fact that two kinds of talk exist within radio news - institutional talk and pioneering talk in Israel, or institutional talk and plain talk in the United States - suggests that journalists use differential address to simultaneously address different publics through one news item or broadcast. ${ }^{7}$ It is unclear who links up with which discourse: pioneering talk and plain talk may be oriented to domestic audiences who are encouraged to connect with (or at least understand) ongoing ideological issues of concern - while institutional talk may be oriented toward more general and possibly foreign markets. Alternate scenarios might provide for the foreign-audience appeal to be held by the strong ideological dimensions of embedded discourses.

Both scenarios suggest that journalists use notions of 'place' to connect their news relays with larger cultural and ideological discourses, thereby helping different publics to appropriate content in accordance with them. Journalists fit notions of 'place' in the news inside larger cultural and ideological discourses. This means that in all three kinds of news-talk, 'place' is seen less as a geographical locus and more as (a) a reinforcement of institutional phenomena in the news; and (b) a link-up with ongoing cultural and ideological discourses in society. Multiple maps exist, by which certain geographics are often more institutionalized than others.

Places remain long after the news is gone. In the fashion of Bakhtin's (1981) chronotopes, which bind time and space to community, it may be that notions of 'place' consolidate communities. So too may the different notions of 'place' in the news flesh out a public's symbolic relationships with its physical surroundings. More important, by making 'place' into a locus where everybody is allowed inside, they assist the news in perpetuating itself.

\section{Notes}

* The author thanks Dell Hymes, Larry Gross, Keya Ganguly, and James Hay for their comments on earlier drafts. She also thanks Itzhak Roeh for helpful assistance with Hebrew translations. A version of this article was presented at the 1990 meetings of the Speech Communication Association, in Chicago, Illinois.

1. This study bears a certain bias, in that I have used American stylebooks (Garvey and Rivers 1982; Dary 1970; Bittner and Bittner 1977; Bliss and Patterson 1971; Robinson 1971; Crump 1981) to compare both Israeli and American news because no Israeli stylebooks were available to me. Generally, however, Israeli journalistic guidelines follow those of American news.

2. For a discussion of how these practices are accomplished in television news, see Zelizer (1990).

3. A contrasting reference which did not work as a taken-for-granted case of place-formation was Kol Yisrael's employment of the term sichot modiiniyot (intelligence consultations): 
this alternately means government intelligence consultations in Jerusalem, military intelligence consultations at Tel Aviv military headquarters, or meetings of the Mossad (Israel's national intelligence agency) at undefined locations. In this case, one practice did not generate one notion of 'place'.

4. While I lack conclusive data about how newspeople themselves regard different kinds of talk, two stories about Israeli and foreign journalists working in Israel suggest a degree of distinctiveness: (1) One Israeli journalist informant maintains that the same story can be rewritten (for different news shows) with different publics in mind - the domestic public 'which needs ideological nurturing' and the foreign public, which needs its own sense of Israel'. Each version (of the same story) bears its own 'appropriate language'. (2) I myself have had similar journalistic experience when working both at The Jerusalem Post, Israel's English language daily, which rewrote daily stories for an overseas weekly, and as a reporter with Reuters in Israel, which considered 'institutional' topics reported by the local media for inclusion on the wires. In both cases, the inclusion of 'noninstitutional' topics was accomplished by rewriting them into 'institutional' language. At least as concerns journalists in Israel, there thus exist different ways of discussing an item that correspond to constructs of different news audiences.

5. A different focus is demonstrated by the various foreign mass media operating from Israel. Reuters' stylistic handbook, for instance, stipulates the sole use of 'the Israelioccupied territories' when dealing with the West Bank area.

6. Pioneering talk at Kol Yisrael also links specific news items with more general Israeli discourse about notions of 'place': Israel's very nationhood has traditionally been defined around a notion of 'place', and the emergence of planned social settings in accordance with ideological frames of reference (such as kibbutzim or development towns) has made 'place' into a culturally distinct category. For this reason, contemporary discussions of Israel have tended to focus on artifacts of place, myths of place, or the centrality of 'place' in Zionist ideology. See, for example, Hazan (1984) or Bruner and Gorfain (1984).

7. For a discussion of differential address in the news, see Zelizer $(1989,1992)$.

\section{References}

Alexander, Jeffrey (1980). The mass media in systemic, historical and comparative perspective. In Mass Media and Social Change, E. Katz and T. Szechko (eds.). London: Sage Publications.

Bakhtin, M. M. (1981). The Dialogic Imagination. Austin: University of Texas Press.

Bell, Allan (1982). Radio: The style of news language. Journal of Communication 32 (1), 150-164.

Bittner, J. and Bittner, D. (1977). Radio Journalism. Englewood Cliffs, NJ: Prentice-Hall.

Bliss, Edward and Patterson, John (1971). Writing News for Broadcast. New York: Columbia University Press.

Brooker-Gross, Susan (1985). The changing concept of place in the news. In Geography, the Media and Popular Culture, J. Burgess and J. Gold (eds.). New York: St. Martin's Press.

Bruner, E. and Gorfain, P. (1984). Dialogic narration and the paradoxes of Masada. In Text, Play and Story: The Construction and Reconstruction of Self and Society, E. M. Brunner (ed.). Washington, DC: American Ethnological Society.

Condit, C. M. and Selzer, J. A. (1985). The rhetoric of objectivity in the newspaper coverage of a murder trial. Critical Studies in Mass Communication 2 (September), 197-216.

Crisell, Andrew (1986). Understanding Radio. London: Methuen. 


\section{'Place' in radio news}

Crump, Spencer (1981). News-Gathering and Reporting for the 1980s and Beyond. Corono del Mar: Trans-anglo Publishing.

Dary, David (1970). Radio News Handbook. Blue Ridge Summit, PA: Tab Books.

Gans, Herbert (1979). Deciding What's News. New York: Pantheon Books.

Garvey, Daniel E. and Rivers, W. L. (1982). Broadcast Writing. New York: Longman Books. Goffman, Erving (1981). Forms of Talk. Philadelphia: University of Pennsylvania Press.

Hallin, Daniel (1986). Cartography, community and the cold war. In Reading the News, R. K. Manoff and M. Schudson (eds.). New York: Pantheon.

Handelman, Don (1984). Letter. In Text, Play and Story: The Construction and Reconstruction of Self and Society, E. M. Brunner (ed.). Washington, DC: American Ethnological Society. Hazan, Haim (1984). Temporal conceptions of community in a sponsored urban setting. Urban Anthropology 13, 33-64.

Hymes, Dell (1972). Models of the interaction of language and social life. In Directions in Sociolinguistics, J. J. Gumperz and D. Hymes (eds.). New York: Holt, Rinehart and Winston.

Linde, Charlotte and Labov, William (1975). Spatial networks for the study of language and thought. Language 51, 924-939.

Moss, P. and Higgins, C. (1984). Radio voices. Media, Culture and Society 6, 353-375.

Newman, David (1984). Ideological and political influences in Israeli rurban colonization: The West Bank and the Galilee mountains. The Canadian Geographer 28, 142-155.

Robinson, Sol (1971). Guidelines for News Reporters. Blue Ridge Summit, PA: Tab Books. Schegloff, Emanuel (1971). Notes on a conversational practice: Formulating place. In Studies in Social Interaction, David Sudnow (ed.). New York: The Free Press.

Schudson, Michael (1978). Discovering the News. New York: Basic Books.

-(1986). Deadlines, datelines and history. In Reading the News, R. K. Manoff and M. Schudson (eds.). New York: Pantheon Books.

Tuchman, Gaye (1978). Making News. New York: The Free Press.

Zelizer, Barbie (1989). 'Saying' as collective practice: Quoting and differential address in the news. Text 9 (4), 369-388.

-(1990). Where is the author in American TV news? On the construction and presentation of proximity, authorship, and journalistic authority. Semiotica $89(1 / 2), 37-48$.

-(1992). Covering the Body: The Kennedy Assassination, the Media, and the Shaping of Collective Memory. Chicago: University of Chicago Press.

Barbie Zelizer (b. 1954) is Assistant Professor of Rhetoric and Communication at Temple University, in Philadelphia, Pennsylvania. Her principal research interests include media, cultural studies, journalism, semiotics, and collective memory. Her most recent book is Covering the Body: The Kennedy Assassination, the Media, and the Shaping of Collective Memory (1992). 